\title{
COPING STRES KARYAWAN DALAM MENGHADAPI STRES KERJA
}

\author{
Oleh: \\ Wiari Utaminingtias, Ishartono, \& Eva Nuriyah Hidayat \\ E-mail: \\ wiariutm@gmail.com
}

\begin{abstract}
ABSTRAK
Kemajuan era globalisasi menimbulkan berkembangnya industrialisasi di Indonesia. Banyak perusahaan-perusahaan berdiri di Indonesia bak perusahaan dalam negeri maupun perusahaan swasta. Semakin banyaknya perusahaan yang berdiri akan memicu persaingan antar perusahaan yang semakin ketat. Perusahaan bersaing untuk menjadi yang terbaik. Karyawan merupakan ujung tombak dari sebuah perusahaan, karena karyawan merupakan aset bagi perusahaan untuk dapat menjalankan aktivitas perusahaan untuk mencapai kepentingan bisnis perusahaan. Karyawan dituntut unuk bekerja lebih giat, cepat, dan ulet untuk mencapai target bisnis perusahaan. Tidak jarang banyak perusahaan tidak sadar bahwa beban kerja yang diberikan kepada karyawan terlalu berat sehingga membuat karyawan mengalami stres kerja. Stres kerja akan menurunkan produktivitas karyawan sehingga akan merusak kinerja alam perusahaan itu sendiri. Coping merupakan upaya dalam menghadapi masalahnya, coping yang dilakukan setiap orang akan berbeda-beda. Dalam stres dikenal dengan coping stres, coping stres sendiri adalah upaya seseorang untuk mengatsi masalahnya yang dianggap sebagai stressor (sumber stres) untuk mengurangi atau menghilangkan rasa stres yang dirasakannya. Pekerja sosial Industri merupakan profesi yang dapat mengatasi masalah tersebut. Pada peneitian ini pekerja sosial dapat menjembatani antara kepentingan karyawan dengan perusahaan agar kegiatan perusahaan dapat berjalan dengan baik. Metode penelitian yang digunakan dalam penelitian ini adalah metode penelitian kuantitatif. Metode penelitian kuantitatif dipilih dengan berbagai pertimbangan yang akan terjadi pada saat dilapangan.
\end{abstract}

Kata kunci: Coping Stres, Stres Kerja, Pekerja Sosial Industri

\section{ABSTRACT}

The progress of globalization cause the growth of industrialization in Indonesia. Many companies established in Indonesia tub domestic enterprises and private companies. Increasing number of companies that stand will trigger competition between companies is getting tougher. Companies compete to be the best. Employees are the spearhead of a company, because the employee is an asset for the company to be able to run the activities of the company to achieve the company's business interests. Employees required to transform and work harder, faster, and resilient to reach the target company's business. Not infrequently many companies are not aware that the work load is too heavy given to employees so that employees experience work stress. Work stress will reduce the productivity of the employees that will damage the natural performance of the company itself. Coping is an effort in the face of problems, coping is done everyone will be different. In a known stress coping with stress, coping with stress itself is a person attempts to override the problem is regarded as a stressor (a source of stress) to reduce or eliminate the stress he felt. Industry is a professional social worker 
who can resolve the issue. At this peneitian social workers can mediate between the interests of employees with the company so that the company's activities can be run well. The method used in this research is quantitative research methods. Quantitative research methods have been a number of considerations that will occur at the time of the field.

Key words: Coping Stress, Work Stress, Social Work In Workplace

\section{PENDAHULUAN}

Pada era globalisasi ini, teknologi semakin berkembang sehingga memicu pertumbuhan ekonomi yang menyebabkan dunia usaha juga berkembang secara pesat. Perkembangan dunia usaha menimbulkan banyak perusahaan berdiri di era indutrialisasi ini. Dalam kemajuan berdirinya banyak perusahaan di Indonesia, semakin banyak perusahaan yang membutuhkan sumber daya manusia untuk menjalankan aktivitas perusahaan.Sumber daya manusia atau karyawan merupakan aset bagi perusahaan. Semakin ketatnya persaingan dunia usaha, menuntut perusahaan untuk mencari sumber daya yang berkualitas untuk dapat meningkatkan keuntungan perusahaan. Perusahaan dituntut bekerja dengan ritme yang serba cepat dan bersifat kompetitif dan karyawan merupakan alat bagi perusahaan untuk mencapai tujuan perusahaan (keuntungan) agar dapat bertahan di persaingan dunia usaha.

Persaingan dunia usaha yang semakin ketat membuat karyawan dituntut bekerja dengan performa yang baik. Tidak jarang dunia pekerjaan akan membuat karyawan merasa stres karena tuntutan perusahaan agar terus meningkatkan kinerja semaksimal mungkin. Rasa was-was, tegang, dan stres mungkin telah menjadi bagian dari karyawan dalam menjalani aktivitas perusahaan untuk memenuhi tanggung jawab mereka terhadap tugas-tugas yang harus dijalankan. Stres kerja merupakan kondisi yang dialami oleh pekerja atas interaksinya dengan pekerjaannya, biasanya stres terjadi karena adanya ketidaksesuaian antara pekerjaan dengan karyawan sehingga menimbulkan ketegangan dan rasa cemas.
Morgan dan King mengatakan bahwa stres kerja disebabkan oleh tuntutan fisik, lingkungan, dan sosial yang tidak terkendali yang dimana hal tersebut melebihi kemampuan karyawan untuk dapat megatasinya.

(http://repository.usu.ac.id/bitstream/1234567 89/20617/3/Chapter\%20II.pdf)

Stres bukan hanya berdampak kepada karyawan saja namun kepada perusahaan juga. Stres dapat menyebabkan kinerja karyawan menurun yang akan mengakibatkan kepada pencapaian tujuan perusahaan. Stres bukan hanya berdampak kepada karyawan saja namun kepada perusahaan juga. Stres dapat menyebabkan kinerja karyawan menurun yang akan mengakibatkan kepada pencapaian tujuan perusahaan. Sebagaimana dikutip pada Kompas Cyber Media bahwa:

“...secara langsung dan tidak langsung akan berdampak kepada banyaknya urusan korporasi yang terbengkalai. Mengganggu proses bisnis tentu akan mengganggu hasil yang diharapkan. Jika kita hubungkan dengan biaya, maka sungguh sangat besar kerugian yang harus ditanggung korporasi akibat stres yang terus menggerogoti kesehatan karyawan. Biaya kesehatan yang terdiri dari perawatan dan pengobatan akan melonjak dengan sangat signifikan. Kemudian akibat suasana lingkungan kerja yang tidak kondusif, akan memicu turn over karyawan dengan cepat. Mereka yang merasa tidak nyaman, akan cenderung mencari korporasi yang membuat mereka bebas atau minimal tidak tertular oleh stres rekan kerjanya. Turn over yang tinggi atau banyaknya karyawan yang keluar dan masuk akan menambah beban biaya HRD, khususnya untuk rekrutmen dan pelatihan, yang jelas tidak 
murah."'http://bisniskeuangan.kompas.com/re $\mathrm{ad} / 2015 / 02 / 16 / 070700526 /$ Stres.Karyawan.da n.Perusahaan diunduh pada tanggal 2 april 2015)

Dalam sebuah perusahaan pasti terdapat target bisnis yang harus dicapai dalam kurun waktu tertentu. Marketing merupakan salah satu bagian yang ditugaskan sebagai pencapaian target perusahaan. Target bisnis dalam perusahaan dapat menjadi stressor untuk karyawan khususnya bagian marketing. Target bisnis yang diberikan berlebihan rentan membuat karyawan akan mengalami stres karena karyawan yang tidak dapat mencapai target yang diberikan.

Pada www.gajimu.com menjelaskan bahwa stres yang dialami karyawan dalam rentang waktu seminggu. Terdapat karyawan yang tidak mengalami stres sebanyak $5,85 \%$ sedangkan sisanya hampir semua mengalami stres. Bahkan sebanyak $15.00 \%$ menyatakan bahwa dirinya mengalami stres setiap hari atau disebutkan dalam table daily (5 hari kerja). Persentase tertinggi adalah $39.02 \%$ karyawan mengalami stres dalam 3 hari kerjanya dalam waktu seminggu (5 hari kerja).

Stres seharusnya menjadi perhatian utama untuk perusahaan karena stres pada karyawan juga akan berdampak pada perusahaan itu sendiri. Bekerja dalam kondisi stres akan menurunkan produktivitas dan performa karyawan sehingga akan merugikan perusahaan sendiri. Maka dari itu, stres, pada karyawan penting untuk dikaji pada penelitian ini.

Pada dasarnya setiap manusia akan melakukan sesuatu untuk dapat mengatasi atau menghadapi masalah yang sedang dialaminya, tindakan itu biasa disebut coping. Dalam stres, biasa disebut dengan coping stres. Coping stres adalah upaya seseorang untuk mengatasi masalahnya yang menjadi stressor. Coping yang dilakukan setiap orang akan berbedabeda, begitupun dengan karyawan dalam menghadapi stres kerja. Coping stres disini diartikan sebagai upaya karayawan dalam menghadapi stres kerja, dimana peneliti akan melihat bengtuk dari coping dari karyawan tersebut.

Maka dari itu, coping stres karyawan dalam stres kerja penting untuk dikaji. Coping juga dapat bersifat negatif, seperti pemakaian obatobatan terlarang, minuman keras, dan narkotika. Jika karyawan melakukan coping yang bersifat negatif akan merugikan dirinya sendiri dan juga perusahaan. Perusahaan akan kehilangan karyawan-karyawan untuk melakukan aktivitas perusahaan.

Pekerja sosial industrial berfungsi menjembatani antara kepentingan karyawan dan perusahaan karena seharusnya di antara keduanya ada keseimbangan. Keseimbangan yang dimaksud adalah bagaimana kedua belah pihak dapat memperoleh benefit dan kenyamanan yang diharapkan. Pekerja sosial industrial menitik beratkan kepada keseimbangan karyawan dan perusahan dalam bentuk : (1) Perusahaan dapat mencapai target bisnis yang diharapkan (2) Karyawan memiliki hak untuk diperhatikan kondisi emosional yang dapat menyebabkan stress oleh perusahaan.

Pada penelitian ini diharapkan perusahaan juga ikut serta dalam coping stres karyawan, agar karyawan tidak melakukan bentuk coping yang akan berpengaruh buruk terhadap perusahaan. Dengan begitu, perusahaan akan berjalan dengan kondusif jika kedua belah pihak mendapatkan kepentingan yang diinginkan.

\section{PEMBAHASAN}

\section{A. Stres Kerja}

Stres dalam pekerjaan atau disebut dengan stres kerja adalah suatu tanggapan adaptif, ditengarahi perbedaan individual dan atau proses psikologis, yaitu konsekuensi setiap kegiatan (lingkungan), situasi atau kejadian eksternal yang membebani tuntutan psikologis atau fisik yang berlebihan terhadap seseorang. Selain itu, menurut Robbin (1998) mengatakan bahwa stres kerja merupakan suatu kondisi dinamik individu dikonfrontasi oleh peluang, kendala, dan tuntutan, yang 
dikaitan dengan apa yang sangat diinginkannya dan yang hasilnya dipersepsikan sebagai tidak pasti dan tidak penting (dalam Jurnal Penelitian Psikologi, Pengaruhi Pelatihan Shalat Terhadap Prokrastinasi dan Stres Kerja Pekerja Muslim dan Muslimah).

Stres kerja merupakan salah satu masalah yang dihadapi oleh karyawan dalam lingkungan kerjanya, sumber stres dapat terjadi karena pengaruh internal perusahaan maupun ekstrenal perusahaan. Stres kerja yang dimaksud dalam penelitian ini adalah perasaan tertekan, cemas dan tegang yang dialami oleh karyawan karena beberapa sumber stres yang dipengaruhi oleh tuntutan pekerjaan, relasi antar karyawan, dan tuntutan eksternal (seperti masalah rumah tangga) yang dipengaruhi oleh lingkungan pekerjaannya (lingkungan perusahaan). Terdapat banyak sumber yang membuat para karyawan sehingga mengalami stres kerja. Dalam masalah stres kerja ini, bukan hanya individu (karyawan) yang harus berusaha menyelesaikan namun lingkungan yang mempengaruhinya pun juga harus berperan dalam upaya mengatasi rasa stres kerja tersebut. Sebagaimana yang dikatakan oleh Rice stres kerja adalah stres yang dialami oleh individu dimana melibatkan juga pihak organisasi atau perusahaan tempat individu bekerja (Dalam Skripsi yang berjudul Stres Kerja Pada Karyawan).

Menurut Robbins (1998) sumber stres kerja (Work Stressor) yang paling berpotensial adalah yang pertama faktor lingkungan yaitu ketidakpastian ekonomis, ketidakpastian politis, ketidakpastian teknologi. Kedua, faktor organisasi yaitu tuntutan tugas, tuntutan peran, tuntutan antra pribadi, struktur organisasi, kepemipinan organisasi, dan tahap organisasi. Ketiga, faktor individual yaitu masalah kelurga, masalah ekonomi, dan kepribadian. (dalam Jurnal Penelitian Psikologi, Pengaruhi Pelatihan Shalat Terhadap Prokrastinasi dan Stres Kerja Pekerja Muslim dan Muslimah). Selain itu, Terdapat penyebab tekanan kerja (dalam Panji dan Ninik, 1993) yang menyebabkan stres kerja yaitu sebagai berikut

1. Tekanan hidup instrinsik dalam kerja. Karyawan akan mengalami stres jika mempunyai terlalu banyak beban kerja. Stres dikarenakan beban kerja dibagi menjadi :

a. Kelebihan kerja secara kuantitatif: yaitu suatu kejadian dimana seseorang diberikan terlalu banyak pekerjaan atau tanggung jawab dalam waktu yang terbatas.

b. Kelebihan kerja kualitatif : yaitu melakukan pekerjaan yang sukar dan rumit untuk dilaksanakan.

c. Kekurangan waktu dalam melaksanakan suatu pekerjaan.

2. Peranan dalam organisasi yang dikelompokan dalam dua bagian, yaitu:

a. Konflik dalam peranan, ini muncul bila terdapat tuntutan yang berbeda dalam pekerjaannya, perbeedaan antara tuntutan pekerjaan dengan ciriciri pribadi dan kecakapan sendiri. Atau bisa dikatakan stres ini muncul bila karyawan ini tidak tahu hasil yang diharapkan dari pekerjaan yang didapatkannya

b. Kekaburan dalam peran, ini akan timbul bila peranannya dalam bekerja dari segi ruang lingkup, tanggung jawab dan apa yang diharapkan darinya tidak jelas karena pekerjaan itu mempunyai struktur dan definisi yang lemah.

3. Pekembangan karier dalam organisasi. Tekanan hidup atau stress ini muncul bila seseorang itu dinaikkan pangkatnya tapi tidak selaras dengan kemampuan atau tidak mendapatkan pangkat yang sesuai dengan kontribusinya dalam bekerja. Reaksi dalam stress ini adalah rasa gemetar dan kurang yakin bila ia hendak mengambil berbagai tindakan dalam menjalankan tugasnya. 
4. Kurang jaminan dalam bekerja. Stress juga dapat timbul jika pekerja takut ketinggalan zaman dalam bekerja atau merasa dirinya out of date.

5. Hubungan dalam organisasi. Stres ini muncul jika seorang pekerja memiliki hubungan yang tidak baik, apakah itu dengan pemimpinnya, teman sejawatnya ataupun para bawahannya. Hal ini juga berkaitan erat dengan kesulitan di dalam mendelegasikan tanggung jawabnya kepada para bawahannya.

6. Keadaan pekerja dalam organisasi. Stres ini akan muncul jika seorang pekerja di dalam rangkaian komunikasi yang ada tidak mendapatkan suatu kejelasan atau tidak ada tempat untuk mengadu atau meminta nasihat tentang pekerjaannya, lebih-lebih jika ia begitu tahu akan apa yang akan terjadi di sekitar situasi kerjanya. Pekerja ini akan kehilangan identitas.

7. Perubahan yang sering dalam organisasi. Perubahan yang dimaksudkan di sini adalah berkaitan dengan orang, seperti mendapat penyelia baru, mutasi, dan dalam kelompok kerja atau penggabungan dengan kelompok kerja lain, atau terpaksa berpisah dengan kelompok kerja ketika itu.

8. Suasana di tempat kerja. Keadaan kerja yang tidak memuaskan akan bisa merusak mutu pekerjaan seseorang. Lama kelamaan kesukaran yang berasal dari tempat kerja ini akan menimbulkan stress dalam dirinya, sebagai contoh; suhu, tingkat kebisingan dan sebagainya.

9. Organisasi dan faktor lain. Kesetiaan yang terbagi antara kehendak organisasi dan kehendak sendiri bisa juga menimbulkan konflik antara tuntutan perusahaan dan keluarga tekanan ini akan membuatnya tidak simpati pada bawahannya atau sengaja mencari kesalahan orang lain dalam suasana kerjanya, atau anggota keluarga sendiri menjadi korban untuk melepaskan teanan yang dihadapinya dalam bekerja.

10. Kehendak intrinsik individu. Kehendak intrinsik ini ialah keadaan pribadi seseorang pekerja, dari segi toleransi terhadap kesangsian, kestabilan dan konsep diri pekerja itu sendiri. Atau dapat dikatakan stres ini muncul bila ada suatu kejadian yang bertentangan dengan kehendaknya sendiri.

Cox mengidentifikasi lima jenis konsekuensi dari dampak stress kerja, meliputi: (a) Subjective effect; (b) Behavioral effect; (c) Cognitive effect; (d) Phsiological effect; (e) Organozational effect. (Dalam Jurnal Penelitian Psikologi)

Subjective effect yaitu karyawan merasa cemas, agresi, acuh, depresi, keletihan, frustasi, kehilangan kesabaran, rendah diri, gugup, dan merasa kesepian.

Behavioral effect yaitu karyawan cenderung akan mengalami kecelakaan, mengkonsumsi alcohol, penyalahgunaan obatobatan, emsi yang tiba-tiba meledak, makan berlebihan, merokok berlebihan, tidur berlebihan, perilaku yang lebih mengikuti kata hati, dan tertawa gugup.

Cognitive effect yaitu ketidakmampuan karyawan dalam mengambil keputusan yang jelas, konsentrasi buruk, rentang perhatian yang pendek, sangat peka terhadap kritik, dan rintangan mental.

Phsiological effect yaitu hal-hal yang berhubungan dengan kondisi tubuh atau kesehatan karyawan seperti meningkatnya kadar gula, meningkatkan denyut jantung dan tekanan darah, kekeringan mulut, berkeringat berlebihan, membesarnya pupil mata, dan tubuh panas dingin.

Organizational effect yaitu meningkatnya ketidakhadiran kerja, pergantian karyawan, rendahnya produktivitas, keterasingan dari rekan kerja, ketidakpuasan kerja, menurunnya kesetiaan terhadap perusahaan. 
Selain itu, Margolis dan kawan-kawan (dalam Jurnal Penelitian Psikologi) juga mengemukakan pendapatnya tentang konsekuensi dari stres kerja yaitu terdapat 10 indikasi stress, yaitu :

1. Kesehatan fisik secara keseluruhan menurun

2. Melakukan tindakan pelarian

3. Murung

4. Merasa harga diri rendah

5. Tidak puas dengan kehidupan

6. Tidak puas dengan pekerjaan

7. Motivasi kerja merosot

8. Bermaksud untuk berhenti dari pekerjaan

9. Sering mengkritik atasan

10. Kerap mangkir

Konsekuensi stress kerja akan berdampak buruk terhadap diri karyawan sendiri dan juga perusahaan. Perusahaan juga akan mengalami konsekuensi dari stres kerja yang dialami karyawan. Randall Schuller (Dalam Jacinta, 2002) mengidentifikasi beberapa perilaku negatif karyawan yang berpengaruh terhadap organisasi. Stres kerja yang dialami oleh karyawan akan berdampak negatif terhadap perusahaan (Dalam Jacinta, 2002) sebagai berikut :

a. Terjadinya kekacauan, hambatan baik dalam manajemen maupun operasional kerja

b. Mengganggu kenormalan aktivitas kerja

c. Menurunkan tingkat produktivitas

d. Menurunkan pemasukan dan keuntungan perusahaan. Kerugian finansial yang dialami perusahaan karena tidak ada keseimbangan antara produktivitas karyawan dengan pengeluaran untuk membayar gaji, tunjangan, dan fasilitas lainnya. Banyaknya karyawan yang tidak hadir dengan berbagai alasan, tugas yang tidak terselesaikan dikarenakan kelambanan ataupun kesalahan yang trejadi berulang kali.
Dengan demikian dapat diketahui bahwa stres kerja bukan hanya berdampak kepada individunya (karyawan) saja namun juga akan berdampak kepada aktivitas perusahaan. Perusahaan mempunyai peran untuk mencegah atau mengatasi stres kerja yang dialami oleh karyawan, karena pada dasarnya karyawan merupakan aset bagi perusahaan.

Jika dianalogikan perusahaan merupakan tubuh manusia sedangkan karyawan adalah anggota tubuh tersebut jika terdapat gangguan salah satu anggota tubuh maka akan menghambat kegiatan tubuh tersebut. Begitu juga dengan perusahaan, jika banyak karyawan yang mengalami kemangkiran kerja maka hal tersebut juga akn berpengaruh buruk terhadap perusahaan.

\section{B. Coping Stres}

"Coping is defined as the person's constantly changing cognitive and behavioral efforts to manage specific external and/or internal demands that are appraised as taxing or exceeding the person's resource." (Dalam Lazarus dalam Dynamics of Stressful Encounter: Cognitive Appraisal, Coping, and Encounter Outcomes, Journal of Personality and Social Psychology, 1986)

Coping didefinisikan sebagai upaya seseorang dalam bentuk kognitif maupun perilaku untuk mengatasi tuntutan eksternal maupun internal yang dianggap sebagai sesuatu yang membebani atau melebihi kemampuan individu tersebut. Upaya yang dilakukan setiap orang akan berbeda-beda, begitupun dalam menghadapi stres.

Santrock (2003) menjelaskan bahwa coping adalah upaya mengendalikan keadaan yang penuh tekanan dengan berusaha untuk mencari jalan keluar atas masalah yang terjadi dan mencari penyebab utama untuk mengurangi stres yang timbul. 
Pada penelitian ini coping stres diartikan sebagai upaya individu dalam menghadapi masalahnya yang menyebabkan stres. Tujuan dari coping yang dilakukan adalah untuk mengurangi rasa stres yang dialaminya, upaya-upaya tersebut akan mempengaruhi langsung terhadap penyelesaian masalah (stressor) atau hanya sekedar upaya individu mengalihkan masalah yang dialaminya.

Pada dasarnya setiap manusia akan melakukan berbagai upaya untuk membuat dirinya nyaman dalam situasi yang menurutnya tidak sesuai dengan keinginannya. Karyawan yang mengalami stres kerja akan melakukan coping untuk mengurangi tekanan yang dialaminya, coping yang dilakukan oleh karyawan dapat berbentuk positif maupun negatif. Coping yang cenderung kearah yag negatif akan merugikan diri karyawan maupun perusahaan.

Menurut lazarus dan Folkman (1984) terdapat dua bentuk coping stres yaitu emotion-focused coping dan problem-focused coping. Emotion-focused coping adalah upaya seseorang dalam mengatasi rasa stresnya yang hanya sebatas mencari makna yang terjadi pada dirinya atau melakukan sesuatu yang dianggap dapat mengurangi rasa stresnya tanpa berusaha mengubah keadaan atau masalah yang sedang dialaminya.

Problem-focused coping adalah upaya seseorang untuk mengatasi masalahnya dengan berusaha mencari jalan keluar atau solusi atau strategi untuk mengubah situasi yang dianggapnya sebagai sumber stres.

Pada emotion-focused coping terdapat beberapa bentuk dari coping stres tersebut, sebagai berikut:

1. Escapism (Pelarian diri dari masalah)

2. Minialization (Meringankan beban masalah)

3. Minimalization (Meringankan beban masalah)

4. Self Blame (Menyalahkan diri sendiri)

\section{Seeking Meaning (Mencari arti)}

Escapism adalah usaha karyawan untuk menghindar dari masalah yang dihadapinya dengan cara berkhayal atau membayangkan jika masalah tersebut terselesaikan atau tidak dalam situasi tersebut. Cara yang dilakukan untuk menghindarinya adalah dengan tidur lebih banyak, minum minuman keras, penyalahgunaan obat-obatan terlarang, dan menolak kehadiran orang lain.

Minimalization merupakan usaha karyawan untuk Individu menghindari masalah dengan cara menolak memikirkan masalah tersebut dan menganggap seolah-olah masalah tersebut tidak ada sehingga dapat mengurangin rasa stresnya.

Self blame merupakan usaha karyawan menghadapi masalahnya dengan cara menghukum dan menyalahkan dirinya sendiri atas segala rasa penyesalan yang ditimbulkan oleh masalah tersebut.

Seeking meaning merupakan usaha karyawan menghadapi masalahnya dengan cara mencari makna dari masalah yang dihadapinya atau mencari hikmah dari kegagalannya yang penting dalam kehidupannya.

Rogers dan Rippetor (dalam jurnal 1987 : 596-604) Emotion-focused coping berdasarkan penggolongannya dibagi menjadi dua, yaitu :

1. Adaptif adalah coping yang mendukung fungsi integrasi, pertumbuhan, belajar dan mencapai tujuan. Kategorinya adalah berbicara dengan orang lain, memecahkan masalah secara efektif, teknik relaksasi, latihan seimbang dan aktivitas konstruktif.

2. Maladatif adalah coping yang menghambat fungsi integrasi, memecah pertumbuhan, menurunkan otonomi dan cenderung menguasai lingkungan. Kategorinya adalah makan berlebihan atau tidak makan, bekerja berlebihan dan menghindar.

Pada problem-focused coping terdapat beberapa bentuk dari coping stres tersebut, sebagai berikut: 
a. Instrumental action (tindakan secara langsung)

b. Cautiousness (kehati-hatian)

c. Negotiation (Negosiasi)

Instrumental action adalah upaya karyawan untuk menyelesaikan masalahnya dengan cara melakukan usaha dan merencanakan langkahlangkah yang mengarah pada penyelesaian masalah secara langsung serta menyusun rencana untuk bertindak dan melaksanakannya.

Cautiouness adalah upaya karyawan ynag cenderung berhati-hati dalam mempertimbangkan alternatif pemecahan masalah serta dalam merumuskan masalah, meminta pendapat orang lain, dan mengevaluasi tindakan yang pernah dilakukan sebelumnya.

Negotiation adalah sebuah usaha karyawan untuk membicarakan serta mencari penyelesaian masalah dengan orang lain yang terlibat dengan masalah tersebut dengan harapan masalah akan dapat terselesaikan. Usaha yang dilakukan juga dapat bertujuan untuk mengubah pendapat atau pikiran orang lain demi mendapatkan situasi yang positif.

Coping stres ternyata dipengaruhi oleh beberapa faktor. Berikut faktor-faktor yang mempengaruhi coping stres (Dalam Journal Personality and Social Psychology)

a. Jenis Kelamin

b. Tingkat Pendidikan

c. Perkembangan Usia

d. Status Sosial Ekonomi

Jenis Kelamin ternyata menentukan coping yang dilakukan seseorang. Pada dasarnya lakilaki dan perempuan sama-sama menggunakan kedua bentuk coping yaitu problem focus coping dan emotion focus coping. Namun wanita ternyata lebih cenderung berorientasi pada emosi sedangkan pria lebih berorientasi pada masalah. Secara umum respon coping stres antara pria dan wanita hampir sama, tetapi wanita lebih lemah atau lebih sering menggunakan penyaluran emosi daripada pria.

Coping juga dipengaruhi oleh tingkat pendidikan. Semakin tinggi tingkat pendidikan seesorang akan semakin tinggi pula kompleksitas kognitifnya, demikian pula sebaliknya. Oleh karenanya seseorang yang berpendidikan tinggi akan lebih realistis dan aktif dalam memecahkan masalah.

Perkembangan usia juga mempengaruhi seseorang dalam melakukan coping. Struktur psikologis seseorang dan sumber-sumber untuk melakukan coping akan berubah menurut perkembangan usia dan akan membedakan seseorang dalam merespons tekanan. Pada usia muda akan menggunakan problem focus coping sedangkan pada usia yang lebih tua akan menggunakan emotion focus coping. Hal ini disebabkan pada orang yang lebih tua memiliki anggapan bahwa dirinya tidak mampu melakukan perubahan terhadap masalah yang dihadapi sehingga akan bereaksi dengan mengatur emosinya daripada pemecahan masalah.

Terakhir, coping seseorang dipengaruhi oleh status sosial ekonomi. Status sosial ekonomi yang rendah akan menampilkan coping yang kurang aktif, kurang realistis, dan lebih fatal atau menampilkan respon menolak, dibandingkan dengan seseorang yang status ekonominya lebih tinggi.

\section{Perspektif Pekerjaan Sosial Industri dalam Coping Stres}

Sebagaimana yang diketahui bahwa fokus utama pekerjaan sosial adalah meningkatkan keberfungsian sosial. Setiap menghadapi berbagai masalah, klien tidak hanya berfokus kepada klien saja, melainkan kepada lingkungan, situasi sosial, dan orang-orang penting didalamnya (significant other) yang dapat mempengaruhinya (Dalam Suharto, 2009). Stres kerja yang dihadapi oleh karyawan dipengaruhi oleh lingkungan pekerjaannya mulai dari interaksi antar karyawan, tuntutan tugas (beban kerja, atau masalah yang berasal dari lingkunga eksternal 
yaitu masalah rumah tangga. Stres kerja akan menurunkan performan karyawan sehingga dapat menghambat karyawan dalam menyelesaikan tugas-tugasnya. Seseorang dikatakan berfungsi sosial jika dapat menjalankan tugas-tugasnya atau peranperannya, sedangkan seseorang dikatakan disfungsi sosial jika tidak dapat menjalankan perannya (dalam Suharto, 2009).

Coping stres merupakan sebutan untuk upaya dalam mengatasi stres. Coping yang salah dilakukan oleh karyawan akan berdampak buruk terhadap karyawan maupun perusahaan. Pekerja sosial memiliki peran dalam meningkatkan kapasitas orang dalam mengatasi masalah yang dihadapinya dan juga menghubungkan sumber-sumber yang ada disekitar klien untuk membantu klien mengatasi masalahnya. Perusahaan merupakan salah satu yang memiliki peran besar dalam coping stres, karena bagaimanapun coping yang negatif akan merugikan perusahaan sendiri.

Terdapat beberapa bidang garapan pekerjaan sosial, salah satunya pelayanan sosial di tempat bekerja (social work in the workplace) atau sering disebut sebagai pekerjaan sosial industri. Pekerjaan Sosial Industri dapat didefinisikan sebagai lapangan praktik pekerjaan sosial yang secara khusus menangani kebutuhan-kebutuhan kemanusiaan dan sosial di dunia kerja melalui berbagai intervensi dan penerapan metoda pertolongan yang bertujuan untuk memelihara adaptasi optimal antara individu dan lingkungannya, terutama lingkungan kerja.

Dalam konteks ini, Pekerjaan sosial industri dapat menangani beragam kebutuhan individu dan keluarga, relasi dalam perusahaan, serta relasi yang lebih luas antara tempat kerja dan masyarakat yang dikenal dengan istilah tanggung jawab sosial perusahan atau corporate social responsibility (CSR) (dalam Suharto, 2009).

Bidang garapan pekerjaan sosial industri sendiri adalah program bantuan pegawai, penanganan stres dan burn-out, penempatan dan relokasi kerja, perencanaan pensiun, dan tanggungjawab sosial perusahaan.

Pekerjaan sosial industri sendiri terbagi menjadi dua yaitu pelayanan sosial internal dan pelayanan sosial eksternal. Pelayanan sosial internal meliputi terapi individu, terapi kelompok, dan pengembangan sumber daya manusia. Sedangkan pelayanan sosial eksternal meliputi tanggungjawab sosial perusahaan, pengembangan masyarakat, pengembangan kebijakan sosial, dan advokasi sosial.

Dijelaskan bahwa terdapat beberapa permasalahan sosial yang umumnya ditangani pekerja sosial industri adalah masalah yang terkait dengan dampak negative industrialisasi yang oleh Johnson disingkat menjadi 5A (Dalam Suharto, 2009) :

1. Alienation : perasaan keterasingan dari diri, keluarga, dan kelompok sosial yang dapat menimbulkan apatis, marah, dan kecemasan.

2. Addiction Alcoholism : ketergantungan terhadap alkohol, obat-obat terlarang atau rokok yang dapat menurunkan produktivitas , merusak kesehatan fisik dan psikis, dam kehidupan sosial seseorang.

3. Absenteeism : kemangkiran kerja atau perilaku membolos kerja dikarenakan rendahnya motivasi kerja, perasaanperasaan malas, tidajk berguna, tidak merasa memiliki perusahaan, atau sakit fisik dan psikis.

4. Accidents : kecelakaan kerja diakibatkan oleh menurunnya konsentrasi pegawai atau oleh lemahnya sistem keselamatan dan kesehatan lingkungan kerja.

5. Abuse : bentuk-bentuk perlakuan salah terhadap anak-anak atau pasangan dalam keluarga, seperti memukul dan menghardik secara berlebihan yang ditumbulkan oelh frustasi, kebosanan dan kelelahan ditempat pekerjaan. 


\section{PENUTUP}

Pemaparan diatas menjelaskan bagaimana permasalahan-permasalah tersebut dapat menurunkan produktivitas karyawan yang berdampak buruk terhadap pekerjaannya sehingga pencapaian bisnis perusahaan tidak terpenuhi. Stres kerja juga dapat mengakibatkan meningkatnya kemangkiran kerja (absenteeism), keterlambatan, rendahnya produktivitas dan menurunnya kemampuan melakukan tugas-tugas, untuk sebagian orang alkohol, narkotika dan obat-obatan terlarang (addiction alcoholism) tidak jarang digunakan sebagai pelarian atau sarana untuk membantu menghadapi situasi-situasi yang semakin kompleks.

Sebagaimana yang telah dijelaskan bahwa pelarian merupakan bentuk dari emotion-focused coping, jika banyak dari karyawan yang melakukan bentuk coping dengan cara mengkonsumsi alkohol dan narkotika, maka damapk negatif akan teadi juga terhadap perusahaan.

Dalam penelitian ini bermaksud pekerja sosial menjembatani antar kepentingan karyawan dengan perusahaan, dimana keduanya akan merasakan kenyamanan. Dalam pekerjaan sosial terdapat model pelayanan sosial, model pelayanan sosial pada penelitian ini adalah model pelayanan sosial bagi pegawai.

Model pelayanan sosial bagi pegawai ini ditujukan untuk memenuhi kebutuhan para pegawai suatu perusahaan secara individual. Manfaat yang diperoleh bukan hanya untuk karyawan tetapi bermanfaat bagi perusahaan juga karena dapat meningkatkan kepuasan kerja, produktivitas dan kesetiaan pegawai terhadap perusahaannya (Dalam Suharto, 2009). Pekerja sosial berperan sebagai mediator yang menjembatani antara pihak perusahaan dan pihak karyawan agar menemukan titik tengah yang dapat memberikan kenyamanan bagi karyawan.

\section{DAFTAR PUSTAKA}

Buku

Edi Suharto. 2009. Pekerjaan Sosial di Dunia Industri. Bandung: Alfabeta

Budhi Wibhawa, Santoso T. Raharjo \& Meilany Budiarti. 2010. Dasar-dasar Pekerjaan Sosial. Bandung: Widya Padjadjaran.

Burhan Bungin. 2011. Metodologi Penelitian Kuantitatif. Jakarta: Kencana Prenada Media Group

Panji Anogoro dan Ninik Widiyanti. Psikologi dalam Perusahaan. Jakarta : PT. Rineka Cipta

Richard S. Lazarus dan Alan Monat. 1991. Stress and Coping an Anthology Third Edition. Newyork: Columbia University Press

\section{Buku Elektronik}

Richard S. Lazarus dan Susan Folkman. 1984. Stress, Appraisal, and Coping. Newyork: Spinger Public Company, Inc.

Jurnal Cetak

Aldwin, C.M. \& Revenson, T.A. 1987. Does Coping Help? A Reexamination of the Relation Between Coping and Mental Healty. Journal of Personality and Social Psychology, Vol. 53, No. 2, 337348.

Herson Yogi \& Niken Widiastuti. Coping Stres Ibu yang Anak Tunggalnya Meninggal. Jurnal Ilmiah Psikologi. Vol. 15, No. 2, 132-143

Mierrina. 2011. Pengaruh Pelatihan Shalat Terhadap Prokrastinasi dan Stres Kerja Pekerja Muslim dan Muslimah. Jurnal Penelitian Psikologi. Vol. 2, No. 01, 149-164

\section{Jurnal Elektronik}

Effendi, R, W., Tjahjono, E. 1999. Hubungan Perilaku Coping dan Dukungan Sosial Dengan Kecemasan Pada Ibu Hamil Anak Pertama. Jurnal: Anima. Vol 14, No. 54, Hal 214-228 
Susan Folkman, Richard S. Lazarus, Christine Dunkel-Schetter, Anita Delongis, and Rand J. Gruen. 1986.

Dynamics of Stressful Encounter: Cognitive Appraisal, Coping, and Encounter Outcomes. Journal of Personality

and Social Psychology. Vol 50, No.5, Hal. 992-1003.

\section{Internet}

http://bisniskeuangan.kompas.com/read/2015/ 02/16/070700526/Stres.Karyawan.dan. Perusahaan diunduh pada tanggal 2 April 2015
Eingrit Permaitiyas. Stres Kerja dan Strategi Coping Karyawan Frontliner (Teller) Bank. Melalui, http://ejournal.umm.ac.id diunduh pada tanggal 10 April 2015

http://www.policy.hu/suharto/modul_a/makin do_26.htm diunduh pada tanggal 2 april 2015

Jacinta F. Rini. "Stres Kerja". Melalui http://www.e-psikologi.com/artikel/ organisasi-industri/stress-kerja diunduh pada tanggal 10 April 2015 